\section{Get stronger together}

In 2021, you want to be focusing on your patients, and enjoying your dentistry.

There is no better time to join Rodericks Dental, a clinically-led dental provider, dedicated to supporting practices and ensuring delivery of excellent quality care.

When you become part of Rodericks, you will become stronger. The responsibilities of running your practice will be managed and the whole team will enjoy wonderful benefits, like access to quality training and on-going support.

Joining the family offers stability; find out how you could improve your working environment and elevate patient services when you join Rodericks Dental.

For more information visit www. sellyourdentalpractice.net or contact Holly Mahoney at acquisitions@rodericksdental. co.uk or on 01604602491 (option 4).

\title{
Are the new dates in your diary yet?
}

Have you heard? The next British Dental Conference and Dentistry Show will be held on Friday 13 and Saturday 14 May 2022, at the Birmingham NEC.

The show will once again bring a packed two-day programme for all members of the dental team to enjoy. With hours of verifiable $\mathrm{CPD}$, world-class speakers, a dynamic selection of topics and discussions, as well as the chance to discover new innovations and socialise with colleagues, it really will have it all.

As we prepare for a better year than last, make sure you get the dates in your diary so you don't miss out in 2022.

For more information, visit www. thedentistryshow.co.uk, call 02073485270 or email dentistry@closerstillmedia.com.

\section{Direct composites made}

\section{to last}

Strength, beauty, value and endurance

- this is what patients want from

restorations. But what if they knew that this could be achieved in one visit?

\section{COLTENE's BRILLIANT}

COMPONEER - prefabricated veneer

shells - will enable dentists to offer

exceptional restorations in a single appointment.

As for more benefits to you, dentists using BRILLIANT COMPONEER report how the material is easy to handle, the results are great, and it is a cost-effective choice too.

With the shells being so thin, optimal healthy tooth structure is preserved, making BRILLIANT COMPONEER a minimally invasive solution.

Contact COLTENE to find out how its materials could upgrade your restorations viawww.coltene.com, email info.uk@ coltene.com or call 08002545115 .

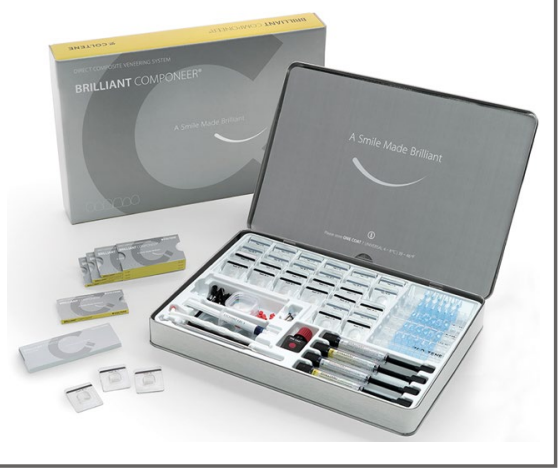

\section{Powerful protection in all areas}

In a dental practice, infection control is of vital importance. As such, you need cleaning products that not only effectively eliminate threats, but can also be used on a variety of surfaces and delicate equipment.

The Steri-7 Xtra range of disinfectants from Initial Medical is a dependable choice.

The range comprises of surface cleaners, hand washes, wipes and more, meaning that solutions can be efficiently used across every surface in your practice. Furthermore, even though the powerful formula kills $99.9999 \%$ of bacteria, viruses and other pathogens, it is still gentle enough to be used on delicate equipment.
As an added bonus the Steri-7 Xtra range is imbued with Reactive Barrier Technology - this means that after application they

prevent pathogens from recolonising surfaces for up to 72 hours - providing exceptional protection between cleaning cycles.

For further information

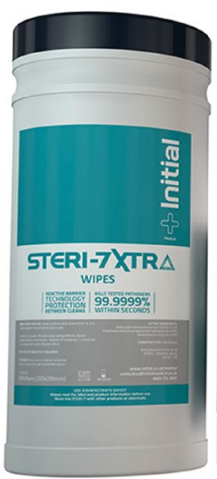

please visit www.initial.co.uk/medical or call 08708504045 .
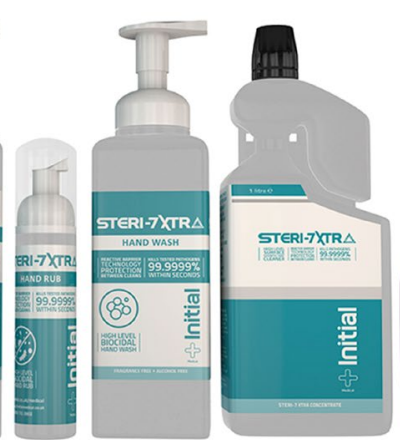